\title{
New chemical constituents of Ambrosia psilostachya
}

\author{
Athar Ata $^{\mathrm{a} *}$, Courtney Diduck ${ }^{\mathrm{a}}$, Chibuike C. Udenigwe ${ }^{\mathrm{a}}$, Shamsulhaq Zahid, \\ and Andreas Decken ${ }^{b}$ \\ ${ }^{a}$ Department of Chemistry, The University of Winnipeg, 515 Portage Avenue, Winnipeg, \\ Manitoba, Canada R3B 2E9 \\ ${ }^{b}$ Department of Chemistry, University of New Brunswick, P. O. Box 45222, Fredericton, NB, \\ Canada E3B $6 E 2$ \\ E-mail:a.ata@uwinnipeg.ca
}

\section{Dedicated to Prof. Atta-ur-Rahman, one of the eminent natural product chemists of the present time, on his $65^{\text {th }}$ Birthday}

\begin{abstract}
Phytochemical studies on the methanolic extract of Amrosia psilostachya, native to Manitoba, have resulted in the isolation of two new sterols, ambrosinal A (1) and ambrosinal B (2) along with a known sesquiterpene lactone, coronopilin (3). Spectroscopic methods were used to establish the structures of these new and known compounds. Single crystal X-ray diffraction studies on compound 3 were also performed. Compounds 1-2 exhibited moderate antibacterial activity against pathogenic bacteria while compound $\mathbf{3}$ was weakly active in glutathione $S$ transferase inhibition assay.
\end{abstract}

Keywords: Ambrosia psilostachya, ambrosinal A, ambrosinal B, coronopilin, antibacterial activity and glutathione $S$-transferase

\section{Introduction}

Ambrosia psilostachya, commonly known as "Perennial ragweed", is abundant in Winnipeg. These weeds vary in leaf size, height, hardness as well as color and many other features. This plant produces natural products to which many people are allergic. The aqueous extract of the flowers of this plant is used to heal and localize bleeding. ${ }^{1}$ Previous chemical studies on $A$. psilostachya, collected from Arizona, yielded two compounds, arrivacins A (4) and B (5). ${ }^{2}$ Compounds $\mathbf{4}$ and $\mathbf{5}$ are reported to exhibit bioactivity in the bovine adrenal membrane where they bind to the angiotensin II receptors. ${ }^{3}$ 
Our research group is involved in discovering natural products exhibiting acetylcholinesterase (AChE) and glutathione $S$-transferase (GST) inhibitory and antimicrobial activities from different natural sources including plants, marine organisms and microorganisms. ${ }^{4-7}$ Antibiotic resistance amongst bacterial pathogens threatens the treatment of infectious diseases. New antibiotics are needed to combat this situation. ${ }^{7}$ In our continuing effort to discover new antibacterial compounds, we discovered that the crude methanolic extract of A. psilostachya and one of the fractions obtained from column chromatography of the crude extract of this plant exhibited antibacterial activity against Streptococcus pyogenes, Staphylococcus aureus, Escherichia coli, Enterococcus faecalis, Pseudomonas aeruginosa, Corynebacterium xerosis, and Bacillus subtilis at a concentration of $50 \mu \mathrm{g} / \mathrm{ml}$. Our detailed phytochemical studies on the crude methanolic extract of this plant resulted in the isolation of two new sterols, ambrosinal A (1) and ambrosinal B (2) along with one known natural product, coronopilin (3). Structures of these new and known natural products were established with the aid of extensive spectroscopic studies. Single crystal X-ray diffraction studies on compound $\mathbf{3}$ were also carried out to confirm its structure (Scheme 1). Compounds 1-2 exhibited moderate antibacterial activity against $S$. pyogenes, S. aureus, E. coli, E. faecalis, $P$. aeruginosa, C. xerosis, and B. subtilis. Compound $\mathbf{3}$ was weakly active in glutathione $S$-transferase (GST) inhibition assay. In this paper, we report the isolation and characterization of compounds $\mathbf{1 - 3}$ as well as their bioactivity data.

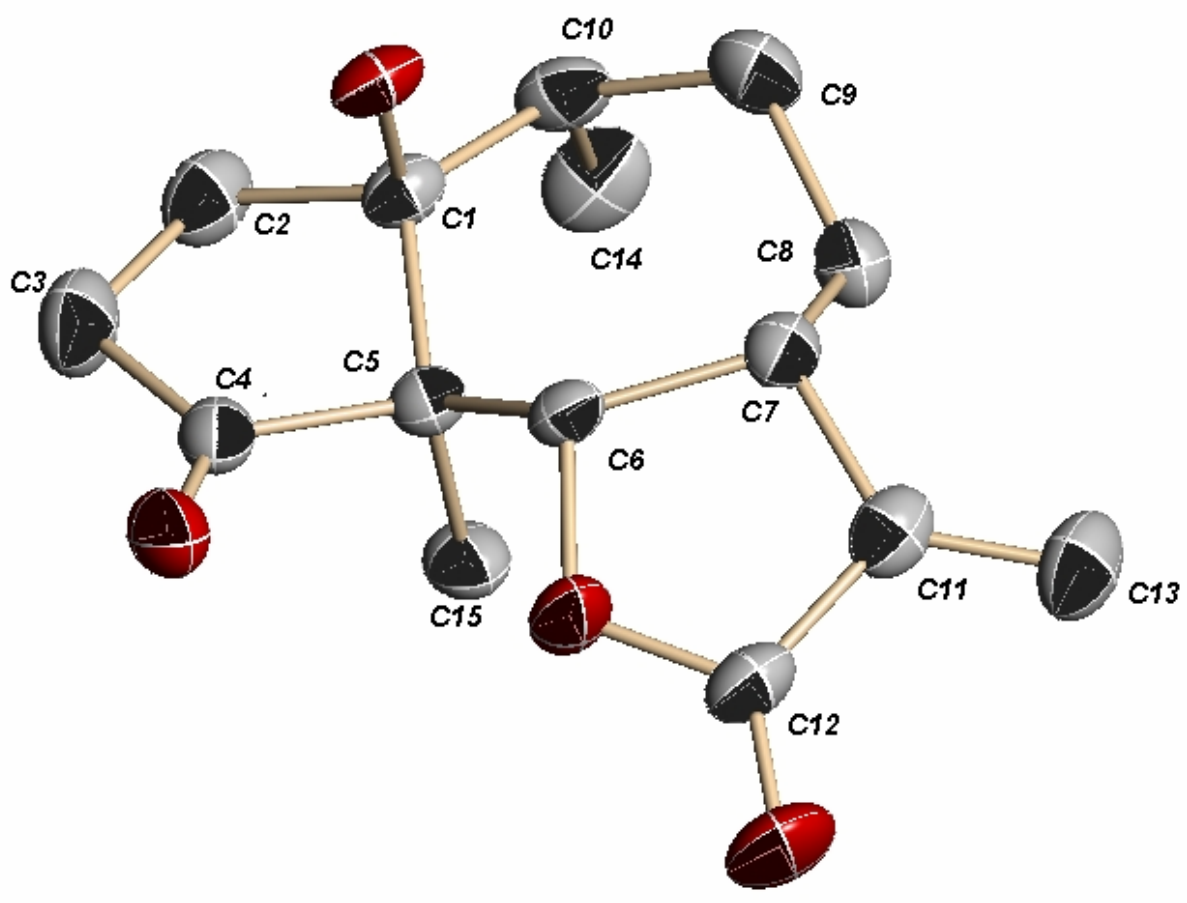

Scheme 1. X-ray structure of compound (3). 


\section{Results and Discussion}

Our first compound, ambrosinal A (1), was isolated as a colorless amorphous solid. Its UV spectrum showed terminal absorption indicating the lack of a conjugated $\pi$ system in 1 . The IR spectrum of 1 displayed intense absorption bands at $3425(\mathrm{OH}), 1723(\mathrm{C}=\mathrm{O})$ and $1598(\mathrm{C}=\mathrm{C})$ $\mathrm{cm}^{-1}$. The high-resolution electron-impact mass spectrum (HREIMS) showed a molecular ion peak at $m / z 414.3501$ corresponding to the molecular formula $\mathrm{C}_{28} \mathrm{H}_{48} \mathrm{O}_{2}$ (calcd 414.3497) and indicated the presence of six degrees of unstauration in compound $\mathbf{1}$.

The ${ }^{1} \mathrm{H}-\mathrm{NMR}$ spectrum $\left(\mathrm{CDCl}_{3}, 300 \mathrm{MHz}\right)$ of 1 showed two three-proton singlets at $\delta 0.65$ and 1.00 due to the C-18 and C-19 methyl protons, respectively. Three doublets, integrating for three protons each, at $\delta 0.85,0.88$ and 0.90 were ascribed to the C-21, C-26 and C-27 methyl protons, respectively. The $\mathrm{C}-3$ methine proton resonated at $\delta 3.55$ while $\mathrm{C}-6$ olefinic hydrogen appeared at $\delta 5.40$. A signal at $\delta 9.81$ was due to the proton of an aldehyde functional group. The COSY $-45^{\circ}$ spectrum was used to assign the ${ }^{1} \mathrm{H}-\mathrm{NMR}$ chemical shift assignments of $\mathbf{1}$. The C-3 methine proton $(\delta 3.55)$ showed vicinal couplings with the $\mathrm{C}-2$ methylene $(\delta 2.00$ and 1.65$)$ and $\mathrm{C}-4$ methine $(\delta 2.16)$ protons. The $\mathrm{C}-2$ methylene protons exhibited ${ }^{1} \mathrm{H}-{ }^{1} \mathrm{H}$ spin correlations with the $\mathrm{C}-1$ methylene protons $(\delta 1.78$ and 1.43$)$. The $\mathrm{C}-4$ methine proton $(\delta 2.16)$ showed crosspeaks with an aldehydic proton $(\delta 9.81)$ and allylic couplings with the C-6 olefinic proton $(\delta$ 5.40). These COSY interactions indicated to us that an aldehyde moiety was substituted at C-4. The ${ }^{13} \mathrm{C}$-NMR spectrum $\left(\mathrm{CDCl}_{3}, 75 \mathrm{MHz}\right)$ of 1 showed the resonance of all twenty eight carbon atoms. The DEPT experiment was also performed to establish the multiplicity of each carbon signal in the broadband ${ }^{13} \mathrm{C}$-NMR spectrum and revealed the presence of five methyl, ten methylene, nine methine carbons. Subtraction of the DEPT spectrum from a broadband ${ }^{13} \mathrm{C}$ NMR spectrum suggested the presence of four quaternary carbon atoms in $\mathbf{1}$. The C-3 resonated at $\delta$ 73.2. Its downfield chemical shift value was due to the presence of a geminal hydroxyl group. A signal at $\delta 198.5$ was ascribed to the C-28. The HSQC spectrum of $\mathbf{1}$ was also recorded to establish ${ }^{1} \mathrm{H} /{ }^{13} \mathrm{C}$ one-bond shift correlations of all protonated carbon atoms. Complete ${ }^{13} \mathrm{C}$ NMR chemical shift assignments of 1 and ${ }^{1} \mathrm{H} /{ }^{13} \mathrm{C}$ one-bond shift correlations of all hydrogenbearing carbon atoms in 1, as determined from HSQC spectrum, are presented in Table-1. 

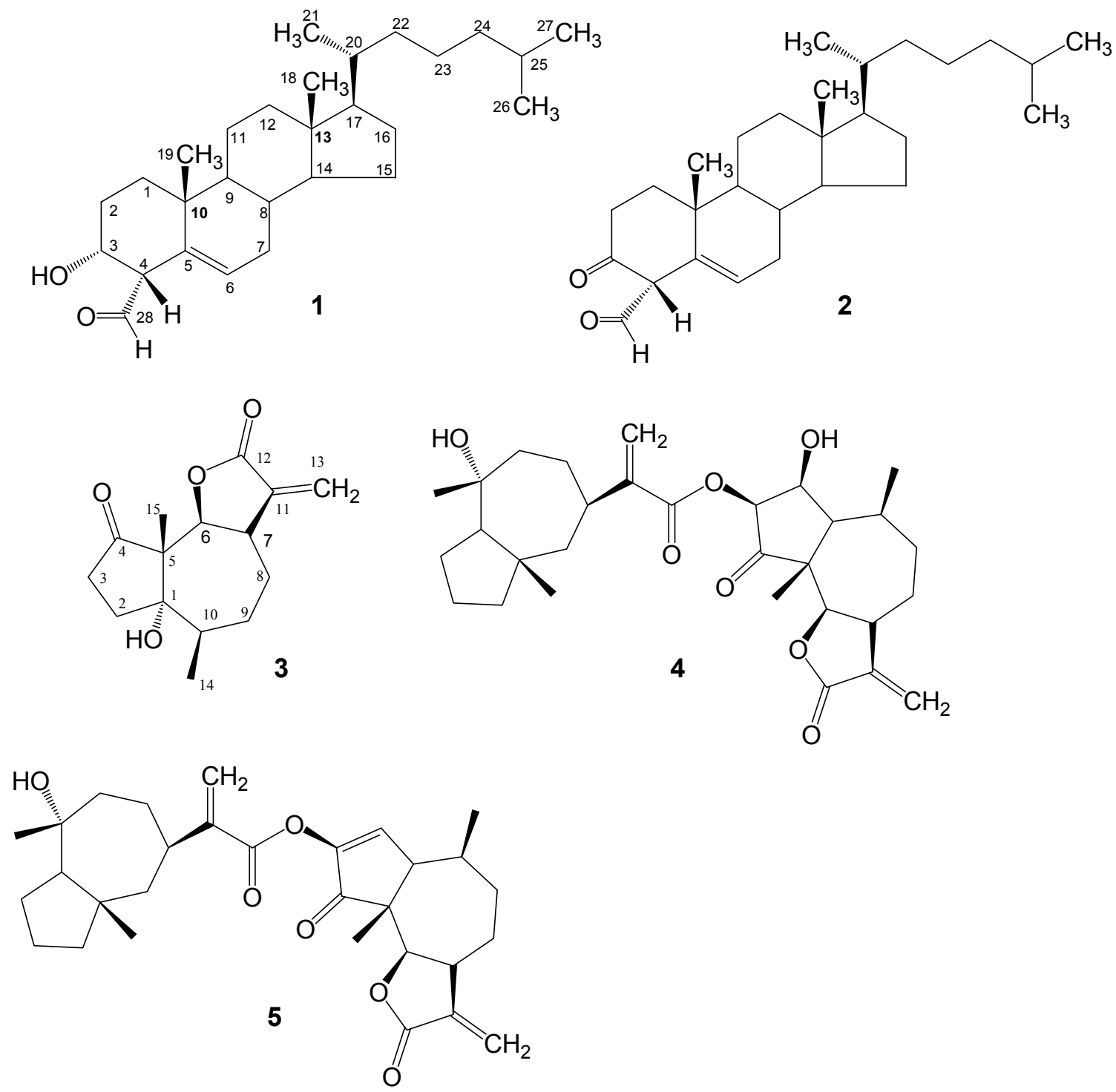

A combination of ${ }^{1} \mathrm{H}$ and ${ }^{13} \mathrm{C}$ spectral data of $\mathbf{1}$ suggested that compound $\mathbf{1}$ has a sterol like structure, as most of the chemical shift values of this compound were distinctly similar to those of steroids. ${ }^{8-10}$ The HMBC spectrum of 1 was very informative in determining the position of various substituents. The aldehydic proton $(\delta$ 9.81) showed cross-peaks with $\mathrm{C}-3(\delta 73.2), \mathrm{C}-4$ $(\delta$ 48.5) and C-5 $(\delta$ 137.5), respectively. The C-3 methine proton $(\delta 3.55)$ exhibited HMBC interactions with C-2 $(\delta 39.1), \mathrm{C}-4(\delta 48.5)$ and C-28 ( $\delta$ 198.5), respectively. The long-range heteronuclear couplings of C-6 methine proton $(\delta 5.40)$ with C-5 $(\delta 137.5), \mathrm{C}-4(\delta 48.5)$ and C28 ( $\delta 198.5)$ were also observed in the HMBC spectrum. These HMBC interactions can only be satisfied by substituting an aldehyde moiety at C-4.

The relative stereochemistry at the various chiral centers of $\mathbf{1}$ was established with the aid of NOESY spectrum, and by comparison of ${ }^{1} \mathrm{H}$ and ${ }^{13} \mathrm{C}$-NMR chemical shift values of $\mathbf{1}$ with those of sterols reported in the literature. ${ }^{8-10} \mathrm{~A}$ cis relationship between $\mathrm{C}-8$ methine $(\delta 1.50), \mathrm{C}-18$ ( $\delta$ $0.65)$ and $\mathrm{C}-19(\delta 1.00)$ methyl protons was observed in the NOESY spectrum. It has been 
reported in the literature that $\mathrm{H}-8, \mathrm{H}_{3}-18$ and $\mathrm{H}_{3}-19$ have $\beta$-orientation in sterols. ${ }^{8-10}$ The ${ }^{1} \mathrm{H}$ - and ${ }^{13} \mathrm{C}-\mathrm{NMR}$ chemical shift values of $\mathrm{H}-8, \mathrm{H}_{3}-18$ and $\mathrm{H}_{3}-19$ were also nearly identical to those of sterols reported in the literature ${ }^{8-10}$. Based on these observations, $\beta$-orientation of $\mathrm{H}-8, \mathrm{H}_{3}-18$ and $\mathrm{H}_{3}-19$ was assumed. The $\mathrm{C}-3(\delta 3.55)$ and $\mathrm{C}-4$ ( $\left.\delta 2.16\right)$ methine protons showed cross-peaks with the $\mathrm{C}-19$ methyl proton $(\delta 1.00)$ suggesting that $\mathrm{H}-3$ and $\mathrm{H}-4$ also have $\beta$-orientation in this compound. The stereochemistry at C-9, C-14 and C-17 was also assumed to be same as reported for other sterols in the literature ${ }^{10}$. Based on these spectral data, structure $\mathbf{1}$ was established for this new sterol.

Our second compound, ambrosinal B (2) was also isolated as a colorless amorphous solid. Its UV and IR spectra were similar to those of compound 1 with an exception that the IR spectrum of 2 did not show absorption band for a hydroxyl functionality. An additional band at $1748 \mathrm{~cm}^{-1}$ indicated the presence of a second carbonyl group in compound 2. The HREIMS of $\mathbf{2}$ showed a molecular ion peak at $\mathrm{m} / z 412.3337$ which provided the molecular formula $\mathrm{C}_{28} \mathrm{H}_{46} \mathrm{O}_{2}$ (calcd 412.3341). This molecular formula indicated the presence of seven degrees of unsaturation in this compound. The mass spectrum indicated to us that compound 2 was a C-3 oxo derivative of $\mathbf{1}$, as most of the fragments were appearing at 2 amu less than those of $\mathbf{1}$. The ${ }^{1} \mathrm{H}-\mathrm{NMR}$ spectrum $\left(\mathrm{CDCl}_{3}, 300 \mathrm{MHz}\right)$ of 2 showed the absence of a signal due to the $\mathrm{C}$-3 hydroxyl-bearing methine proton and rest of the ${ }^{1} \mathrm{H}-\mathrm{NMR}$ spectrum was nearly identical to that of $\mathbf{1}$. This further suggested that compound 2 was a C-3 oxo derivative of $\mathbf{1}$. This was confirmed by recording the ${ }^{13} \mathrm{C}-\mathrm{NMR}$ spectrum and it showed a downfield shift of C-3 signal from $\delta 72.3$ to $\delta 200.1$. A combination of mass, ${ }^{1} \mathrm{H},{ }^{13} \mathrm{C}$, COSY, HSQC and HMBC spectral data further confirmed that compound 2 was a 3-oxo derivative of compound $\mathbf{1}$. Complete ${ }^{1} \mathrm{H}$ - and ${ }^{13} \mathrm{C}$-NMR chemical shift assignments of compound 2, as well as its ${ }^{1} \mathrm{H} /{ }^{13} \mathrm{C}$ one-bond shift correlations of $\mathbf{2}$, as determined from HSQC spectrum, are shown in Table- 1 .

After confirming that compound $\mathbf{2}$ was a 3-oxo derivative of compound $\mathbf{1}$, we used NOESY spectrum to establish the relative stereochemistry at all chiral centers. The NOE data was similar to those of compound $\mathbf{1}$ and this helped us to assume that all of chiral centers have same stereochemistry as those of compound 1. Based on these spectroscopic studies, structure 2 was established for this new sterol.

Additionally, we have also isolated a known compound, coronopilin (3) from this plant. The mass, ${ }^{1} \mathrm{H},{ }^{13} \mathrm{C}$ NMR spectral data compound $\mathbf{3}$ were identical to those of coronopilin, reported in the literature. ${ }^{11}$ The $[\alpha]^{24}=29.4^{\circ}$ of 3 was found to be nearly identical to that of coronopilin reported in the literature $[\alpha]^{21} \mathrm{D}=30.2^{\circ} .{ }^{11}$ This led us to assume that all chiral centers in 3 have same stereochemistry as those of coronopilin reported in the literature. Single crystal X-ray diffraction studies on compound $\mathbf{3}$ were also carried out to confirm its structure. 
Table 1. ${ }^{1} \mathrm{H}$ and ${ }^{13} \mathrm{C}$ NMR chemical shift assignments of compounds $\mathbf{1}$ and $\mathbf{2}$, and ${ }^{1} \mathrm{H} /{ }^{13} \mathrm{C}$ onebond shift correlations of $\mathbf{1}$ determined from HSQC spectrum

\begin{tabular}{|c|c|c|c|c|}
\hline \multirow[b]{2}{*}{ Carbon } & \multicolumn{2}{|l|}{1} & \multicolumn{2}{|l|}{2} \\
\hline & ${ }^{1} \mathrm{H}$ & ${ }^{13} \mathrm{C}^{\dagger}$ & ${ }^{1} \mathrm{H}$ & ${ }^{13} \mathrm{C}^{\dagger}$ \\
\hline \multirow[t]{2}{*}{1.} & $1.78(\mathrm{~m})$ & $31.8(\mathrm{t})$ & 1.87 & $31.7(\mathrm{t})$ \\
\hline & $1.43(\mathrm{~m})$ & & 1.22 & \\
\hline \multirow[t]{2}{*}{2.} & $2.00(\mathrm{~m})$ & $39.1(\mathrm{t})$ & $2.40(\mathrm{~m})$ & $38.8(\mathrm{t})$ \\
\hline & 1.65 & & $2.15(\mathrm{~m})$ & \\
\hline 3. & $3.55(\mathrm{~m})$ & 73.2 (d) & --- & $200.1(\mathrm{~s})$ \\
\hline \multirow[t]{2}{*}{4.} & 2.16 & 48.5 (d) & 2.14 & $50.1(\mathrm{~d})$ \\
\hline & $(\mathrm{ddd}, J=8 \cdot 9,5 \cdot 1,1.3 \mathrm{~Hz})$ & & $(\mathrm{dd}, J=7.8,1.9 \mathrm{~Hz})$ & \\
\hline 5. & --- & $137.5(\mathrm{~s})$ & --- & $137.3(\mathrm{~s})$ \\
\hline \multirow[t]{2}{*}{6.} & 5.40 & $132.0(\mathrm{~d})$ & 5.39 & $132.3(\mathrm{~d})$ \\
\hline & $(\mathrm{ddd}, J=5.4,3.9,1.3 \mathrm{~Hz})$ & & $(\mathrm{ddd}, J=5.2,3.5,1.9 \mathrm{~Hz})$ & \\
\hline \multirow{2}{*}{7.} & $2.05(\mathrm{~m})$ & $26.8(\mathrm{t})$ & $2.04(\mathrm{~m})$ & $26.6(t)$ \\
\hline & $1.53(\mathrm{~m})$ & & $1.50(\mathrm{~m})$ & \\
\hline 8. & $1.50(\mathrm{~m}))$ & $31.6(d)$ & $1.49(\mathrm{~m})$ & $31.5(\mathrm{~d})$ \\
\hline 9. & $1.91(\mathrm{~m})$ & 50.9 (d) & $1.89(\mathrm{~m})$ & $51.0(\mathrm{~d})$ \\
\hline 10. & --- & $34.5(\mathrm{~s})$ & --- & $34.4(\mathrm{~s})$ \\
\hline \multirow[t]{2}{*}{11.} & $1.58(\mathrm{~m})$ & $23.0(\mathrm{t})$ & $1.56(\mathrm{~m})$ & $22.8(\mathrm{t})$ \\
\hline & $1.44(\mathrm{~m})$ & & $1.43(\mathrm{~m})$ & \\
\hline \multirow[t]{2}{*}{12.} & $1.71(\mathrm{~m})$ & $29.3(\mathrm{t})$ & $1.69(\mathrm{~m})$ & $28.9(\mathrm{t})$ \\
\hline & $1.58(\mathrm{~m})$ & & $1.60(\mathrm{~m})$ & \\
\hline 13. & --- & $45.8(\mathrm{~s})$ & --- & $45.6(\mathrm{~s})$ \\
\hline 14. & $1.66(\mathrm{~m})$ & $56.7(d)$ & $1.68(\mathrm{~m})$ & $56.6(d)$ \\
\hline \multirow[t]{2}{*}{15.} & $1.76(\mathrm{~m})$ & $24.8(\mathrm{t})$ & $1.80(\mathrm{~m})$ & $25.0(\mathrm{t})$ \\
\hline & $1.64(\mathrm{~m})$ & & $1.66(\mathrm{~m})$ & \\
\hline \multirow[t]{2}{*}{16.} & $2.09(\mathrm{~m})$ & $27.9(\mathrm{t})$ & $2.10(\mathrm{~m})$ & $28.1(\mathrm{t})$ \\
\hline & $1.55(\mathrm{~m})$ & & $1.58(\mathrm{~m})$ & \\
\hline 17. & $1.55(\mathrm{~m})$ & 56.7 (d) & $1.57(\mathrm{~m})$ & $56.9(d)$ \\
\hline 18. & $0.65(\mathrm{~s})$ & $12.1(\mathrm{q})$ & $0.67(\mathrm{~s})$ & $11.9(q)$ \\
\hline 19. & $1.00(\mathrm{~s})$ & $21.9(\mathrm{q})$ & $0.95(\mathrm{~s})$ & $21.7(q)$ \\
\hline 20. & $1.58(\mathrm{~m})$ & $35.4(d)$ & $1.60(\mathrm{~m})$ & $35.3(d)$ \\
\hline 21. & $0.85(\mathrm{~d}, J=6.5 \mathrm{~Hz})$ & $18.9(\mathrm{q})$ & $0.86(\mathrm{~d}, J=6.4 \mathrm{~Hz})$ & $19.0(q)$ \\
\hline \multirow[t]{2}{*}{22.} & $1.51(\mathrm{~m})$ & $36.9(\mathrm{t})$ & $1.49(\mathrm{~m})$ & $36.8(\mathrm{t})$ \\
\hline & $1.31(\mathrm{~m}$ & & $1.35(\mathrm{~m})$ & \\
\hline \multirow[t]{2}{*}{23.} & $1.45(\mathrm{~m})$ & $23.6(t)$ & $1.46(\mathrm{~m})$ & $23.7(t)$ \\
\hline & $1.23(\mathrm{~m})$ & & $1.25(\mathrm{~m})$ & \\
\hline \multirow[t]{2}{*}{24.} & $153(\mathrm{~m})$ & $39.7(\mathrm{t})$ & $1.55(\mathrm{~m})$ & $39.6(t)$ \\
\hline & $1.20(\mathrm{~m})$ & & $1.23(\mathrm{~m})$ & \\
\hline 25. & $1.53(\mathrm{~m})$ & $28.0(\mathrm{~d})$ & $1.57(\mathrm{~m})$ & $27.8(d)$ \\
\hline 26. & $0.88(\mathrm{~d}, J=6.7 \mathrm{~Hz})$ & $22.6(q)$ & $0.89(\mathrm{~d}, J=6.5 \mathrm{~Hz})$ & $22.5(q)$ \\
\hline 27. & $0.90(\mathrm{~d}, J=6.7 \mathrm{~Hz})$ & $22.8(q)$ & $0.89(\mathrm{~d}, J=6.5 \mathrm{~Hz})$ & $22.9(q)$ \\
\hline 28. & $9.81(\mathrm{~d}, J=8.9 \mathrm{~Hz})$ & $198.5(d)$ & $9.84(\mathrm{~d}, J=7.8 \mathrm{~Hz})$ & $198.8(d)$ \\
\hline
\end{tabular}

${ }^{\dagger}$ Multiplicities were determined by DEPT spectrum 
Compounds 1 and $\mathbf{2}$ showed moderate antibacterial activity against Streptococcus pyogenes, Staphylococcus aureus, Escherichia coli, Enterococcus faecalis, Pseudomonas aeruginosa, Corynebacterium xerosis, and Bacillus subtilis at $25 \mu \mathrm{g} / \mathrm{ml}$. Coronopilin (3) showed a moderate concentration-dependent inhibition of the activity of GST with an $\mathrm{IC}_{50}$ value of $120.3 \pm 7.57$ $\mu$ mol. The bioactivity observed for compound 3 might possibly be due to the presence of an $\alpha$, $\beta$-unsaturated lactone moiety. This would led to the formation of a glutathione adduct of coronopilin (3), via Michael reaction, during the assay period to inhibit the activity of GST.

\section{Experimental Section}

General Procedures. EI/CI MS data were obtained on a Hewlett Packard 5989B spectrometer using direct insertion probe (DIP) method. ${ }^{1} \mathrm{H}$ NMR spectra were recorded in $\mathrm{CDCl}_{3}$ on a Varian Inova and an AM 300 Bruker NMR spectrometers at 200 and $300 \mathrm{MHz}$, respectively.The ${ }^{13} \mathrm{C}$ NMR spectra were recorded on an AM 300 Bruker NMR spectrometer at $75 \mathrm{MHz}$ with TMS as an internal standard. The IR spectra were recorded on a Jasco-IRA1 IR spectrophotometer. The UV spectra were recorded on a Shimadzu UV 240 spectrophotometer. The optical rotations were measured on a Polatronic D polarimeter (Hitachi) and the purities of the samples were checked on TLC (silica gel, GF 254 precoated plates, purchased from Merck).

Plant Material. The whole plant of Ambrosia psilostachya DC (1 kg) was collected in August 2005. This plant was identified by Prof. Richard Staniforth, Department of Biology, University of Winnipeg and a voucher specimen (CHE-1) has been deposited in the Natural Product Chemistry Lab, University of Winnipeg.

Extraction and Isolation. $A$. psilostachya $(1 \mathrm{~kg})$ was dried and extracted with methanol $(1 \mathrm{~L})$ at room temperature. The methanol was removed under reduced pressure to prepare a gum (100 $\mathrm{Gm}$ ). This gum was re-dissolved in an aqueous alcoholic solution (water-methanol, 20:80) to carry out solvent-solvent fractionations with hexane to get rid of fats. This defatted extract was loaded onto a silica gel column. This column was eluted with hexane-ethyl acetate $(0-100 \%)$ and ethyl acetate-methanol (0-100\%) to get several fractions. A fraction obtained on elution of silica gel column with hexane-ethyl acetate (70:30) was subjected to preparative TLC using hexanechloroform as a mobile phase (30:70) to purify compounds $\mathbf{1}$ and $\mathbf{2}$. Compound $\mathbf{3}$ was isolated as colorless crystals from another fraction by preparative TLC using $100 \%$ diethylether as a developing solvent. Compound 3 was re-crystallized in methanol by dissolving $10 \mathrm{mg}$ of the compound in $20 \mathrm{~mL}$ of methanol and allowing the solution to air-dry after $48 \mathrm{~h}$, to produce needle-shaped colorless crystals

Ambrosinal A (1). Colorless amorphous solid, $R_{f}=0.32(7.9 \mathrm{mg}),[\alpha]^{25}{ }_{\mathrm{D}}=83^{\circ}\left(\mathrm{CHCl}_{3}, \mathrm{c}=\right.$ 0.34), UV $\lambda_{\max }(\mathrm{MeOH}) \mathrm{nm}:=210 \mathrm{~nm}, \mathrm{IR} v_{3}^{\mathrm{CDCl}} \mathrm{cm}^{-1}: 3425(\mathrm{OH}), 1723(\mathrm{C}=\mathrm{O})$ and $1598(\mathrm{C}=\mathrm{C})$. 
${ }^{1} \mathrm{H}$ and ${ }^{13} \mathrm{C}$ NMR are given in Table 1. EIMS: $m / z 414\left(\mathrm{M}^{+}\right), 413,399,385,370,43$. HREIMS Calcd. $414.3497 \mathrm{C}_{28} \mathrm{H}_{46} \mathrm{O}_{2}$. Found 414.3501 .

Ambrosinal B (2). Colorless amorphous solid, $R_{f}=0.43(6.4 \mathrm{mg}),[\alpha]_{\mathrm{D}}^{25}=58^{\circ}\left(\mathrm{CHCl}_{3}, \mathrm{c}=\right.$ 0.15), UV $\lambda_{\max }(\mathrm{MeOH}) \mathrm{nm}:=206 \mathrm{~nm}$, IR $v^{\mathrm{CDCl}}{ }_{3} \mathrm{~cm}^{-1}: 1748(\mathrm{C}=\mathrm{O}), 1723(\mathrm{C}=\mathrm{O})$ and 1598 $(\mathrm{C}=\mathrm{C}) .{ }^{1} \mathrm{H}$ and ${ }^{13} \mathrm{C}$ NMR are given in Table 1. EIMS: $m / z 412\left(\mathrm{M}^{+}\right), 411,397,383,368,43$. HREIMS Calcd. $412.3341 \mathrm{C}_{28} \mathrm{H}_{44} \mathrm{O}_{2}$. Found 412.3337.

Coronopilin (3). White crystalline solid, $R_{f}=0.64(10 \mathrm{mg}),[\alpha]^{24} \mathrm{D}=29.4^{\circ}(\mathrm{MeOH}, \mathrm{c}=0.17)$; $\mathrm{UV} \lambda_{\max }(\mathrm{MeOH}) \mathrm{nm}:=243 \mathrm{~nm}$. IR $v^{\mathrm{KBr}} \mathrm{cm}^{-1}: 3225(\mathrm{OH}), 2933(\mathrm{CH}), 1621(\mathrm{C}=\mathrm{C}), 1728(\mathrm{C}=\mathrm{O})$ and 1702 (lactone $\mathrm{C}=\mathrm{O}) .{ }^{1} \mathrm{H}$ NMR $\left(\mathrm{CD}_{3} \mathrm{OD}, 300 \mathrm{MHz}\right) \delta:=6.15\left(1 \mathrm{H}, d, J=2.8 \mathrm{~Hz}, \mathrm{H}_{\mathrm{a}}-13\right)$, $5.66\left(1 \mathrm{H}, d, J=2.8 \mathrm{~Hz}, \mathrm{H}_{\mathrm{b}}-13\right), 4.85(1 \mathrm{H}, d, J=7.8 \mathrm{~Hz}, \mathrm{H}-6), 3.40(1 \mathrm{H}, m, \mathrm{H}-7), 2.65(1 \mathrm{H}, d d d$, $\left.J=1.4,4.4,9.6 \mathrm{~Hz}, \mathrm{H}_{\beta}-3\right), 2.41(2 \mathrm{H}, d d d, J=1.9,4.4,9.6 \mathrm{~Hz}, \mathrm{H}-2), 2.30(1 \mathrm{H}, d t, J=4.3,12.6$ $\left.\mathrm{Hz}, \mathrm{H}_{\alpha}-9\right), 2.10(1 \mathrm{H}, m, \mathrm{H}-10), 2.03\left(1 \mathrm{H}, d d d, J=2.2,4.3,12.6 \mathrm{~Hz}, \mathrm{H}_{\beta}-8\right), 1.75\left(1 \mathrm{H}, m, \mathrm{H}_{\alpha}-8\right)$, $1.68\left(1 \mathrm{H}, m, \mathrm{H}_{\alpha}-3\right), 1.62\left(1 \mathrm{H}, m, \mathrm{H}_{\beta}-9\right), 1.17(1 \mathrm{H}, d, J=7.7 \mathrm{~Hz}, \mathrm{H}-14), 1.08(1 \mathrm{H}, s, \mathrm{H}-15) ;{ }^{13} \mathrm{C}$ NMR $\left(\mathrm{CD}_{3} \mathrm{OD}, 75 \mathrm{MHz}\right) \delta:=221.6(\mathrm{C}-4), 172.9(\mathrm{C}-12), 142.9(\mathrm{C}-11), 122.4(\mathrm{C}-13), 85.2(\mathrm{C}-1)$, 81.9 (C-6), 60.6 (C-5), 45.9 (C-7), 43.2 (C-10), 33.0 (C-2), 32.7 (C-3), 31.2 (C-9), 28.5 (C-8), $17.6(\mathrm{C}-14), 14.9(\mathrm{C}-15)$; CIMS $m / z:=265\left(\mathrm{M}^{+}+1\right)$; EIMS $m / z:=264\left(\mathrm{M}^{+}\right), 246,231,218,204$, 191, 163, 141, 123, 95, 55, 43.

X-Ray crystallography. Crystals of coronopilin (3) were grown in methanol by dissolving 10 $\mathrm{mg}$ of the compound in $20 \mathrm{~mL}$ of methanol and allowing the solution to air-dry after $48 \mathrm{~h}$ at room temperature, to produce needle-shaped colorless crystals. Single crystals were coated with Paratone-N oil, mounted using a 20 micron cryo-loop and frozen in the cold nitrogen stream of the goniometer. A hemisphere of data was collected on a Bruker AXS P4/SMART 1000 diffractometer using $\omega$ and $\theta$ scans with a scan width of $0.3^{\circ}$ and $30 \mathrm{~s}$ exposure times. The detector distance was $5 \mathrm{~cm}$. The data were reduced (SAINT) $)^{12}$ and corrected for absorption (SADABS). ${ }^{13}$ The structure was solved by direct methods and refined by full-matrix least squares on $\mathrm{F}^{2}$ (SHELXTL). ${ }^{14}$ All non-hydrogen atoms were refined using anisotropic displacement parameters. Hydrogen atoms were found in Fourier difference maps and refined using isotropic displacement parameters. The X-ray crystal structure data has been deposited at the Cambridge Crystallographic Data Centre (CCDC) with the reference number CDCC 634102.

Antibacterial activity. The antibacterial activity of compound $\mathbf{1}$ and $\mathbf{2}$ was performed by using the Kirby Bayer disc method. ${ }^{15}$

Enzyme inhibition assay. The activity of equine liver GST was determined according to a modification of the method reported by Habig et. al. (1974) ${ }^{16}$ Assays were performed in a thermostated cell compartment at $22^{\circ} \mathrm{C}$ in $100 \mathrm{mM}$ phosphate buffer $\mathrm{pH} 6.5$, in the presence of $5 \mathrm{mM}$ GSH and $1 \mathrm{mM}$ CDNB. GST activity was measured as the rate of release of the GSHCDNB conjugate at $340 \mathrm{~nm}$ using a HP 8452 Diode Array spectrophotometer. Under these conditions, the non-enzymatic conjugation of the substrates was minimal. Activity of the 
compound against GST was based on inhibition of the initial rate of the enzyme activity during a period of 20 seconds. This experiment was run in triplicate.

\section{Acknowledgements}

Financial support provided by Natural Sciences and Engineering Research Council of Canada (NSERC) and Research Corporation, Tucson, USA is gratefully acknowledged. We are also thankful to Dr. Kirk Marat for his help in running NMR experiments.

\section{References}

1. Bassett, I. J.; Crompton, C. W. Can. J. Plant Sci. 1975, 55, 463.

2. Chen, Y.; Bean, M.; Chambers, C.; Francis, T.; Huddleston, M.; Offen, P.; Westley, J.; Carte, B. Tetrahedron 1991, 47, 4869.

3. Lee, H. S.; Oh, W. K.; Choi, H. C.; Lee, J. W.; Kang, D. O.; Park C.S.; Mheen, T.; Ahn, J. S. Phytotherapy Res. 1998, 12, 212.

4. Babar, Z.; Ata, A.; Meshkatalsadat, M. H. Steroids, 2006, 71, 1045.

5. Ata, A.; Conci, L. J.; Orhan, I. Heterocycles, 2006, 68, 2097.

6. Ata, A; Win, H. Y.; Holt, D.; Holloway, P.; Segstro, E. P.; Jayatilake, G. S. Helv. Chim. Acta. 2004, 87, 1090.

7. Ata, A.; Ackerman, J.; Bayoud, A.; Radhika, P. Helv. Chim. Acta. 2004, 87, 592.

8. Masaru, K.; Takaaki, H.; Fumie N.; Hiroshi, M. Steroids, 1979, 34, 285.

9. Li, Y.; Ishibashi, M.; Satake, M.; Chen, X.; Oshima, Y.; Ohizumi, Y.; J. Nat. Prod. 2003, 66, 696.

10. Litourneux, Y.; Khuong-Huu, Q.; Gut, M.; Lukacs, G. J. Org. Chem. 1975, 40, 1674.

11. Herz, W.; Högenauer, G.. J. Org. Chem. 1961, 26, 5011.

12. SAINT 7.23A, 2006, Bruker AXS, Inc., Madison, Wisconsin, USA.

13. SADABS 2004, George Sheldrick, 2004, Bruker AXS, Inc., Madison,Wisconsin, USA.

14. SHELXTL 6.14, George Sheldrick, 2000, Bruker AXS, Inc., Madison,Wisconsin, USA.

15. Iscan, G.; Kirimer, N.; Kurkcuoglu, M.; Baser, K. H. C.; Demirci, F. J. Agric. Food Chem. 2002, 50, 3943.

16. Habig, W. H.; Pabst, M. J.; Jakoby, W.B.; J. Biol. Chem.,1974, 249, 7130. 